Images in...

\title{
An unusual complication of cardiac catheterisation during BMV
}

\author{
Vivek G Raman, Padmakumar Ramachandran, Nitin Kansal
}

Department of Cardiology, Kasturba Medical College, Manipal, Karnataka, India

Correspondence toVivek G Raman, vivekgraman@gmail.com

\section{DESCRIPTION}

Rheumatic heart disease is the most common cause of mitral stenosis, and percutaneous balloon mitral valvotomy (BMV) has stood the test of time as the standard therapy for the same. We describe a very unusual complication of cardiac catheterisation that occurred during an otherwise uneventful procedure.

A 65-year-old woman was diagnosed with severe mitral stenosis due to rheumatic heart disease. She was in atrial fibrillation and was admitted for BMV. She had a history of stroke from which she had recovered. Patient was on oral anticoagulation that was stopped and unfractionated heparin was given instead, prior to the procedure. Patient's mitral valve was suitable for BMV, with no demonstrable left atrial/left atrial appendage clot on transoesophageal echocardiography (TEE). The patient underwent a fluoroscopy and transthoracic echocardiography (TTE) guided BMV. Intraprocedural heparin according to bodyweight $(70 \mu / \mathrm{kg})$ was administered following septal puncture. Intraprocedural ACT was not monitored as the procedure time was only 30 min. Balloon dilatation was done using Inoue balloon. Postdilation TTE showed good commissural splitting with an increase in MV area and a mild postprocedural MR. There was no clot/pericardial effusion with normal interatrial septum (IAS). However, TTE done 10 min after procedure revealed a mass attached to the IAS (figures 1 and 2). Balloon integrity checked immediately was normal. A possibility of IAS haematoma ${ }^{1} /$ thrombus $^{2}$ was considered. TEE subsequently done confirmed that it was an IAS mobile thrombus projecting into both the atria (figure 3). Patient's anticoagulation was intensified. Repeat ECHO done after 1 month showed complete resolution of the clot.

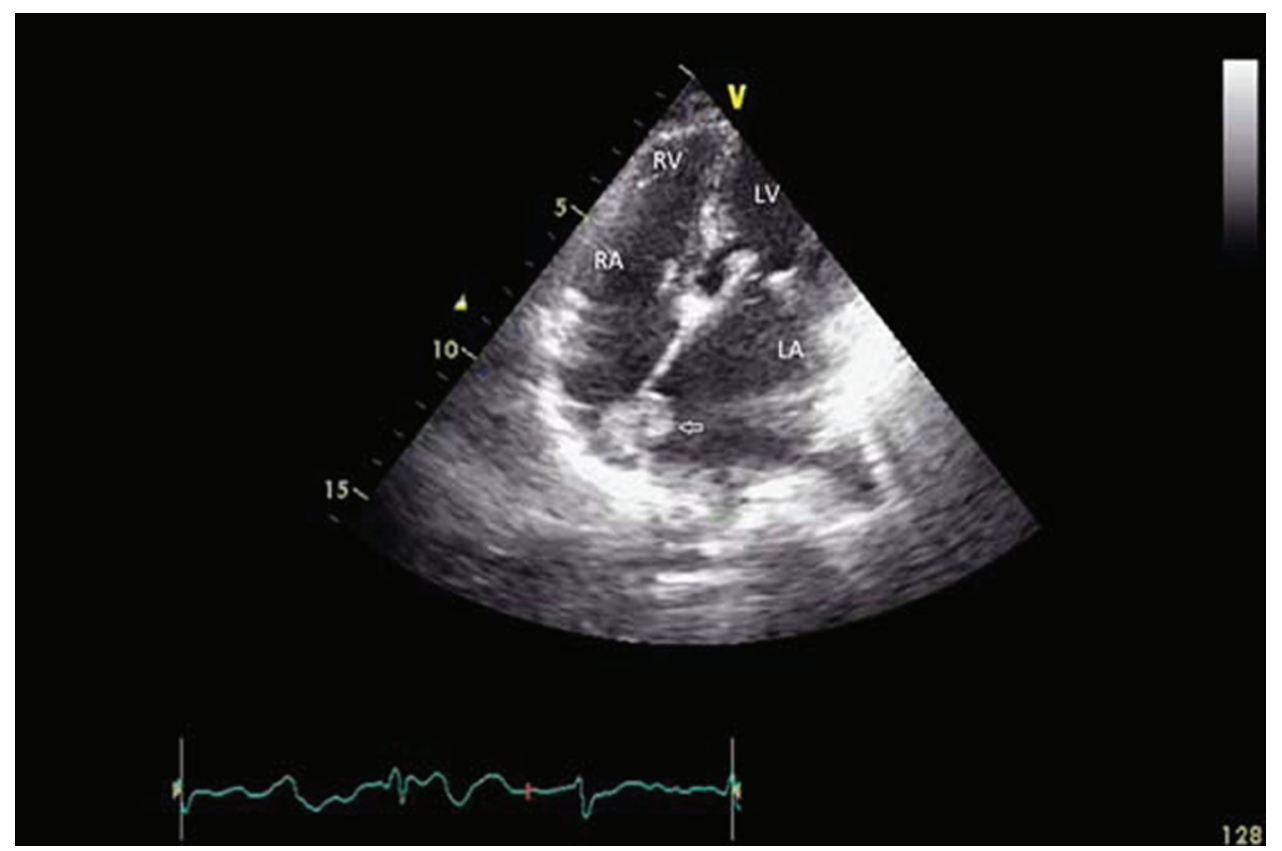

Figure 1 Interatrial septal (IAS) clot - 4-chamber TTE view showing an IAS clot ( arrow). LA, left atrium; RA, right atrium; LV, left ventricle; $\mathrm{RV}$, right ventricle. 


\section{BMJ Case Reports}

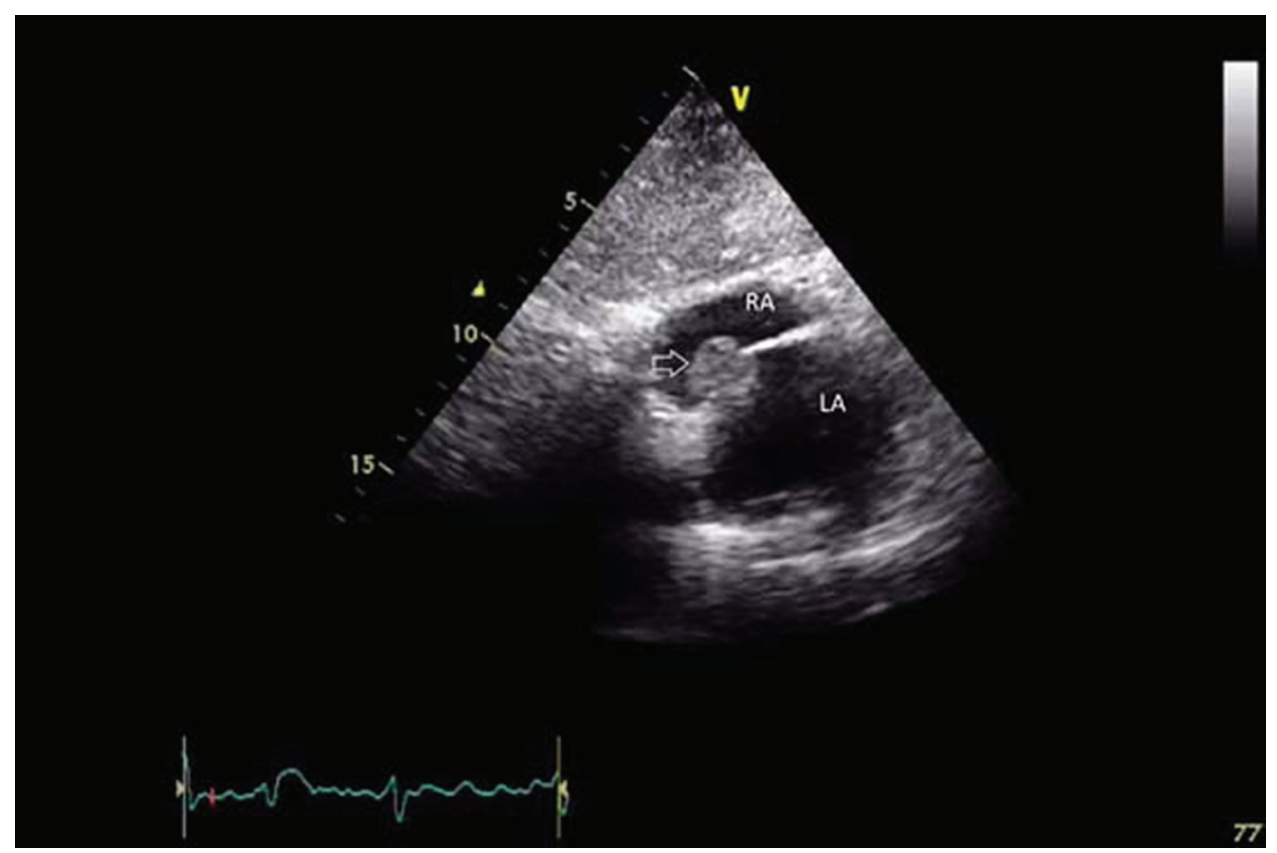

Figure 2 Interatrial septal (IAS) clot - transthoracic subcostal short-axis view showing an IAS clot (arrow). LA, left atrium; RA, right atrium.

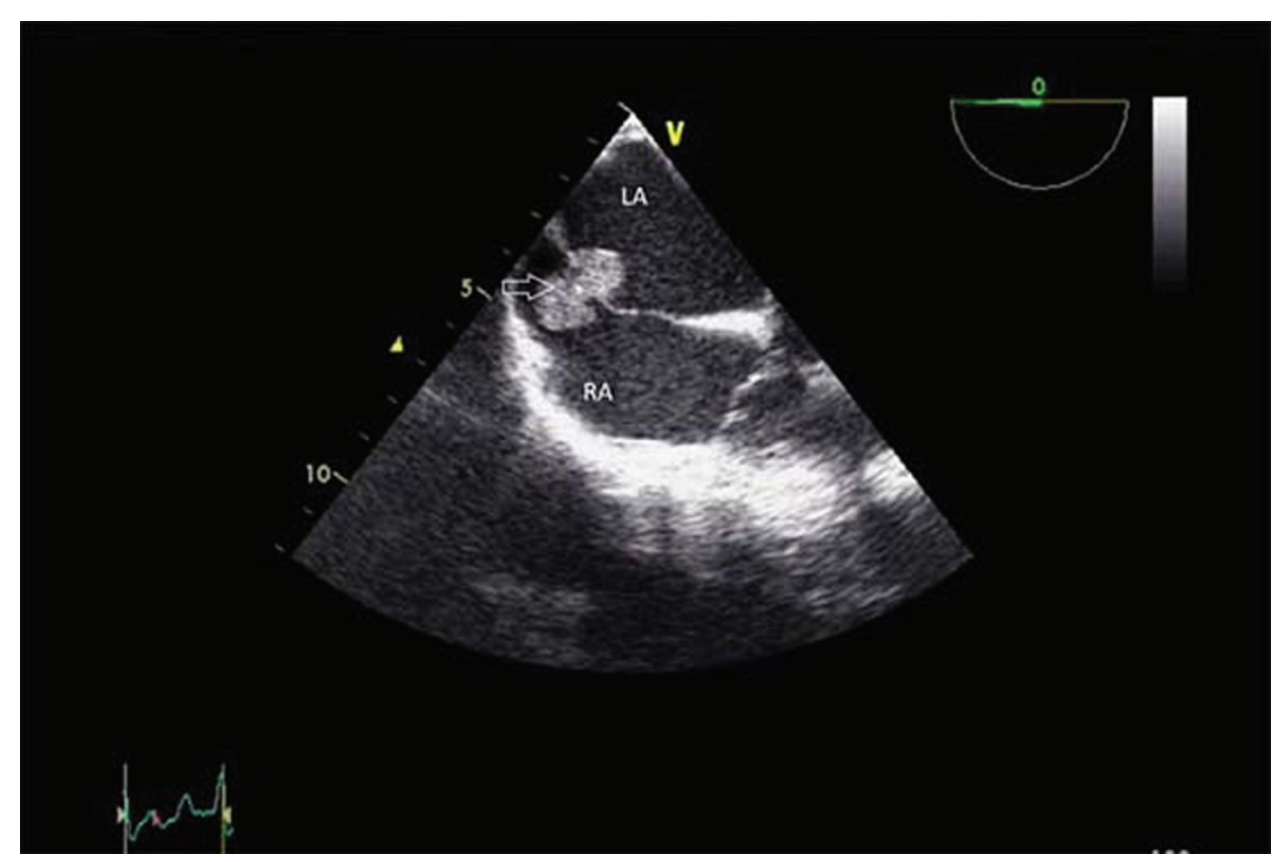

Figure 3 Interatrial septal (IAS) clot - TEE 4-chamber (0 - degree) view showing a dumbbell-shaped interatrial septal clot (arrow) protruding into both atria. LA, left atrium; RA, right atrium.

An IAS thrombus occurring years after BMV has been reported in the literature. ${ }^{2}$ We present this case for its rarity in that an IAS thrombus occurred immediately following BMV.

Competing interests None.

Patient consent Obtained.

\section{REFERENCES}

1. Reshma M, Biniwale MD. Atrial septal hematoma after minimally invasive aortic valve replacement. Tex Heart Inst J 2010; 37:102-5.

2. Furukawa K, Kuwabara M, Nakamura E, et al. Protruding thrombus in the left atrium found 7 years after percutaneous transvenous mitral commissurotomy: report of a case. Surg Today 2003;33:55-7. 


\section{BMJ Case Reports}

This pdf has been created automatically from the final edited text and images.

Copyright 2011 BMJ Publishing Group. All rights reserved. For permission to reuse any of this content visit http://group.bmj.com/group/rights-licensing/permissions.

BMJ Case Report Fellows may re-use this article for personal use and teaching without any further permission.

Please cite this article as follows (you will need to access the article online to obtain the date of publication).

Raman VG, Ramachandran P, Kansal N. An unusual complication of cardiac catheterisation during BMV. BMJ Case Reports 2011;10.1136/bcr.12.2010.3595, date of publication

Become a Fellow of BMJ Case Reports today and you can:

- Submit as many cases as you like

- Enjoy fast sympathetic peer review and rapid publication of accepted articles

- Access all the published articles

Re-use any of the published material for personal use and teaching without further permission

For information on Institutional Fellowships contact consortiasales@bmjgroup.com

Visit casereports.bmj.com for more articles like this and to become a Fellow 